\title{
Um mundo em crise
}

Carlos Altamirano

Tradução de Ana Cristina Arantes Nasser

Examinando-se retrospectivamente a vida pública argentina, no século XX, a década de 1930 adquire valor emblemático. O golpe de Estado de 6 de setembro de 1930, que definiu tanto o término da experiência democrática iniciada em 1912, como a ruptura da continuidade institucional que caracterizou a vida da República desde 1880, costuma ser visto como o começo de uma crise da ordem política que se tornará crônica. Entretanto, a década de 1930 não apenas é evocada para recortar e caracterizar períodos da vida política nacional, mas também é mencionada em referência às mudanças experimentadas pela economia sob efeito da crise econômica mundial - o início da industrialização em substituição às importações, ou seja, a origem da Argentina industrial, remete a essa década -, sem falar nas transformações do mundo social, como José Luis Romero o atesta.

"Os antigos conservadores e seus herdeiros seduzidos pelo fascismo não estavam equivocados ao afirmar que o país tinha se desnaturalizado", escreve Romero, ao elencar as razóes do golpe de Estado, em sua Breve historia de la Argentina. "Após quatorze anos de governo radical [...] revelou-se um fato decisivo: o país criollo desvanecia-se paulatinamente e sobre ele se constituía uma nova Argentina, cuja fisionomia esboçava a mutante composição da sociedade" (Romero, 1996, p. 141). O variado e extenso universo das classes médias constituía o fenômeno mais evidente dessa nova composição.

1. O termo criollo será mantido como tal ao longo do texto, e sempre grafado em itálico, devido à especificidade de seu uso na Argentina, ao fazer referência "aos descendentes dos antigos colonizadores espanhóis que vivem no interior do país, mas não os descendentes dos imigrantes mais recentes, mesmo que descendentes de espanhóis". Disponível em <http://www. wikipédia.com $>$. Acesso em 9/10/09 (N. T.). 
2. A Sociedade Argentina de Escritores (Sade) foi criada para " $[r]$ epresentar, administrar e defender os interesses profissionais dos associados".
Pode-se dizer que o país criollo também ia se desvanecendo, paulatinamente, no âmbito das elites culturais. Durante a década de 1920, esse campo da vida social aumentou seus contingentes e tornou-se mais diferenciado internamente, ou seja, mais complexo. A universidade foi um polo importante dessa evolução. Em Historia de las universidades argentinas, Pablo Buchbinder aponta que devido à Reforma Universitária ocorreu um processo de renovação e ampliação do quadro de professores em todos os locais de ensino do país.

A grande maioria dos que agora compunham a docência universitária já não provinha das eminentes famílias da elite e vivia, em muitos casos, da atividade liberal, ou até mesmo - conforme ocorreu na Faculdade de Filosofia e Letras da Universidade de Buenos Aires - tratava-se de pessoas que fizeram do ensino nos níveis secundário e universitário sua ocupação exclusiva (Buchbinder, 2005, p. 16).

Também influiu para esse aumento no quadro de professores a pressão exercida pelo crescimento da população estudantil: se, “em 1906, havia 1.492 alunos matriculados nas universidades, dez anos depois este número chegava a quase 7 mil, e em 1920 já havia 12.116 matriculados" (Idem, p. 118). E não eram apenas as universidades históricas de Buenos Aires e Córdoba que acolhiam esses alunos, mas também as do Prata e de Rosário, que logo se tornaram centros ativos da vida universitária nacional.

Na década de 1920, ocorreu uma transformação semelhante no âmbito da produção e dos produtores literários. A “república das letras" alargou suas fronteiras com a incorporação de novos membros e, em 1928, a formação de uma união de escritores, a Sade, foi um reflexo desse crescimento $^{2}$. Só uma minoria da geração de novos literati provinha de famílias abastadas ou ostentava sobrenome de estirpe, como Oliverio Girondo ou Jorge Luis Borges. A maioria procedia das classes médias e uma parte, que alimentará a redação das revistas de esquerda e as alas de escritores do grupo de Boedo, tinha origem até mesmo mais plebeia. Em outras palavras, o espaço literário foi povoado de "novos" argentinos, oriundos da imigração. Embora a imigração italiana não fosse a única escola de recém-chegados ao ofício de escritores, a proliferação de sobrenomes italianos dessa proveniência - Castelnuovo, Portogalo, Barletta, Riccio - tornou mais perceptível a transformação. O núcleo criollo dos escritores, o dos "argentinos sem esforço", que "não tinham de dissimular nenhuma pronúncia exótica" - como dirão de si mesmos os redatores de Martín Fierro, ao responder às críticas 
dos defensores da literatura social (os escritores de Boedo) -, verá seu espaço reduzido na nova cena literária ${ }^{3}$, mesmo mantendo, de qualquer forma, o centro da inovação e do prestígio literários.

\section{Tradições de leitura}

A expressão "década de trinta" costuma indicar mais do que um decênio, uma época, que geralmente se estende até 1943, o ano em que outro golpe de Estado pôs fim ao regime conservador. Será que existiu algum modo de pensar o país que se distinguisse dessa época? Formular tal pergunta significa estabelecer uma relação com o trabalho de crítica e balanço da história intelectual do período. Uma tradição de leitura outorgou a representação desses anos a certa espécie de ensaísmo - o ensaio de caráter ontológico sobre o ser coletivo dos argentinos; o ensaio do "ser nacional". Seguramente, o julgamento não é alheio às qualidades literárias dos textos fundamentais dessa corrente. Entretanto, não existe sociedade de relativa complexidade que seja culturalmente uniforme: a Argentina não o era, e seu ambiente intelectual não funcionava conforme um sistema único de referências ideológicas.

Em um excelente artigo sobre a literatura argentina da década de 1930, María Teresa Gramuglio desmantela muitas ideias apresentadas e mostra a diversidade de comunidades ideológicas que animam a vida intelectual da época, desde a esquerda socialista e comunista até a direita nacionalista, e essa versão populista do nacionalismo constituída pela Forja (Força Orientadora Radical da Juventude Argentina). Para Gramuglio, o fundamentalmente diferente dos anos de 1930 - caso se queira captar o espírito do novo - residiu nas páginas de Sur, a revista fundada por Victoria Ocampo em 1931. Ao encontrar seu caminho, após as tentativas dos primeiros anos, Sur " converteu-se na revista literária mais prestigiada da Argentina e, talvez, da América Latina. Ela foi reconhecida e elogiada em revistas de diferentes tendências, como Nosotros, Columna, Conducta e Verbum; publicar em suas páginas chegou a ser, para muitos, um fator de consagração" (Gramuglio, 2001, p. 346).

A afirmação de Gramuglio, enfatizando o papel central de Sur na cena literária argentina da década de 1930, não contradiz (ao menos, não necessariamente) a opinião que confere valor específico ao ensaio destinado a buscar e definir a Argentina essencial. Grande parte dos que cultivaram o gênero - Mallea, Martínez Estrada, Erro, Canal Feijóo - foram membros
3. Martín Fierro, n. 8 e 9 , ago.-set. 1924, p. 56. 
4. "Carta a Ortega y Gasset" [19/7/1930], Sur, n. 347, julho-dezembro de 1980. ou colaboradores regulares da revista, sob cuja rubrica foram editados três dos livros concernentes a esse estilo de reflexão. Por outro lado, a missão americanista que Victoria Ocampo atribuiu a Sur estava em sintonia com esse ensaísmo: conforme escreverá em 1930, a revista que ela tinha em mente "se dedicaria, sobretudo, à questão americana em todos os seus aspectos, e nela colaborariam todos os americanos relacionados à temática, bem como os europeus interessados na América" ${ }^{\prime 4}$.

Certamente, não havia novidade nesse esforço. Excluindo o que fora mencionado, bem como o exemplo sempre à mão do Facundo, de Sarmiento, acaso já não seria esse o propósito de Juan Agustín García, em La ciudad indiana (1900), ao buscar captar os aspectos invariáveis do caráter nacional para explicar - tanto no prólogo, como na conclusão do livro - por que, na Argentina, parecia que sempre o mesmo espetáculo era representado, embora variassem as obras representadas? No entanto, os ensaios de hermenêutica do ser argentino, publicados na década de 1930, diferiam dos precedentes, não só porque a verdade de suas análises não se baseava em "leis" sociológicas ou esquemas conceituais positivistas, mas porque questionavam, juntamente com o presente que reprovavam, os rumos da experiência argentina depois de Caseros.

Radiografía de la pampa (1933), de Ezequiel Martínez Estrada, e Historia de una pasión argentina (1937), de Eduardo Mallea, foram considerados os ensaios de maior penetração, embora não os únicos de uma tendência que também se manifestou em livros como Medida del criollismo (1929) e Tiempo lacerado (1936), de Carlos Alberto Erro; Alma y estilo (1930), de Homero Guglielmini; El hombre que está solo y espera (1931), de Raúl Scalabrini Ortiz; Conocimiento y expresión de la Argentina (1935), também de Mallea; Descontento creador. Afirmación de una conciencia argentina (1943), de Romualdo Brughetti; e Proposiciones en torno al problema de una cultura nacional argentina (1944), de Bernardo Canal Feijóo. O gênero continuaria sendo praticado durante as décadas posteriores, graças, principalmente, aos próprios Martínez Estrada e Mallea, que continuaram cultivando-o. Em contrapartida, Radiografía de la pampa e Historia de una pasión argentina ficaram associados à década de 1930, sendo considerados pela crítica como os frutos mais lúcidos do angustiado questionamento produzido pela crise que envolvia a nação.

A passagem do tempo não transcorreu da mesma forma para os dois textos. O ensaio de Martínez Estrada só recebeu uma segunda edição em 1942, ou seja, nove anos depois da primeira, embora não deixasse de ser reeditado 
desde então; em contrapartida, os livros com os quais o autor continuava explorando a realidade nacional - La cabeza de Goliat (1940), Sarmiento (1946), Las invariantes históricas de Facundo (1947) e, principalmente, Muerte y transfiguración de Martín Fierro (1948) - incrementavam a sua autoridade como intérprete do ser argentino, e, com ela, também a do estudo com o qual iniciara a série. Com o tempo, Radiografía de la pampa conquistou o lugar de um clássico do pensamento e da literatura argentinos. Já no caso de Historia de una pasión argentina, o reconhecimento foi imediato. Desde sua primeira edição, em 1937, o livro de Mallea conheceu "os mais devotos, os mais entusiastas e os mais loquazes leitores dentre os próprios contemporâneos aos quais fora endereçado” (Monegal, 1956, p. 31). No ano seguinte à primeira edição, surgiu outra, acompanhada de um admirável prólogo do filósofo Francisco Romero; e, em 1940, lançou-se uma nova, que continuou sendo regularmente publicada, enquanto sua dicotomia entre os dois países - a Argentina visível, que o livro reprovava, e a Argentina valiosa e verdadeira, mas invisível, que conclamava a aflorar na vida nacional - atuou como livro de reflexão para a fração mais diferenciada da intelligentsia. A revista Sur era o centro dessa elite conspícua "que aplaudiu incessantemente Mallea" (Idem, p. 33). A partir da segunda metade de 1950, a mensagem de Historia de una pasión argentina alcançou cada vez menos adeptos e sua retórica envelheceu, como ocorreria paulatinamente com toda a obra do autor.

É frequente a opinião de que Radiografía de la pampa não obteve a repercussão que merecia entre seus contemporâneos, como se comprova no ensaio já mencionado de Emir Rodríguez Monegal, e também em Esquema de la Argentina, do escritor nacionalista Máximo Etchecopar (cf. Etchecopar, 1956, p. 131). Mais de trinta anos depois, em uma análise sobre a recepção crítica ao livro de Martínez Estrada, o julgamento é repetido por Rodolfo Borello (1993, p. 425). Para Rodríguez Monegal (assim como para Borello, que é seu seguidor), Radiografía de la pampa só alcançou verdadeiros leitores com o surgimento do grupo intelectual que ele batizou como geração dos "parricidas", ou "geração de 1945" - os jovens das revistas Centro, Contorno, Ciudad. É exagerada a tese de que na década de 1930 o livro de Martínez Estrada quase não encontrou eco apropriado. Salvo as breves, embora contundentes, linhas escritas por Borges em uma resenha de 1933 - que terminava com o seguinte parecer: "um admirável estudo" -, bem como o prêmio nacional recebido pelo livro, cabe ao menos registrar que tanto Carlos Alberto Erro, em Tiempo lacerado, como Luis Emilio Soto, em Crítica y estimación 
(1938) (ambos editados pelo selo Sur), ressaltaram o ensaio de Martínez Estrada. Para Erro, a grande contribuição de sua geração para a autocompreensão da identidade criolla encontrava seus textos fundamentais em Don Segundo Sombra, os escritos criollistas de Borges, e em Radiografia de la pampa.

$\mathrm{Na}$ polêmica revisão do processo intelectual e literário que o grupo identificado como "geração de 1945" (ou de 1950, segundo Borello) empreendeu em suas revistas, a leitura de Martínez Estrada já não podia ser aquela dos contemporâneos de Radiografia de la pampa, ainda que isso se devesse exclusivamente à óbvia razão de que muitas coisas aconteceram desde então, tanto no mundo, como na Argentina - o peronismo, em primeiro lugar. Entretanto, mais sugestivo do que a mudança inevitável de perspectiva é o que poderíamos chamar de continuidade da década de 1930 na leitura dos jovens, não só como chave histórica para interpretar os escritos desse período, mas como chave que ainda vigorava no presente. Sobre Eduardo Mallea, Ismael Vinãs disse, por exemplo, que ele "pertence a uma época extremamente próxima, tanto no tempo como nas preocupaçóes. Não se trata apenas de termos sofrido as consequências da época de Mallea [...] mas sim de, estritamente, estarmos vivendo quase a mesma atmosfera" (Viñas, 2004, p. 120). Proximidade no tempo, vigência das mesmas preocupaçōes, atualidade dos males que alguns ousaram revelar em sua época. Tanto antes, como agora, nenhuma questão era mais imperiosa do que defender e expressar a verdade do ser da nação. Fugir da situação nacional, agir como europeus, participar imaginariamente de um mundo cultural que não era o dos argentinos; ou assumir a realidade e testemunhá-la, mesmo que seja desagradável e se perca pureza nesse intento?

Esse é o dilema que, como alternativa ética para a intelligentsia, pode ser reiteradamente encontrado na revisão que os referidos "herdeiros" farão do legado de seus mestres. Mesmo no equivocado balanço de Eduardo Mallea, é possível notar que, pelo menos desde Historia de una pasión argentina, ele enfrentara a realidade, representando, naquela década de 1930, uma das poucas vozes empenhadas em expressar o "desagrado pelos rumos tomados pelo país, culturalmente corrupto e inerte" (Idem, p. 124). Mas o que se admirava no autor de Radiografia de la pampa? O contraditor público dos mitos da Argentina liberal, identificada com o otimismo e a facilidade. "Martínez Estrada representa o momento em que se começa a deixar de ver a Argentina como uma alegoria de futuro otimista e fácil”, escreveu Ismael Viñas, na revista Contorno, acrescentando ainda, para tornar mais clara a sua tese, que: 
O sentimento da grandeza nacional sofre uma ruptura: são muitos os que começam, então, a perceber que o alegre contexto de nossa riqueza e de nosso progresso não é senão uma fachada que oculta muita verdade ruim; que existe uma grande diferença entre as declarações da Constituição e os ritmos da ode $A$ los ganados y las mieses e a realidade do país" (Viñas, 1954).

Radiografía de la pampa brotou da consciência produzida por essa crise, cuja existência e magnitude só alguns se atreveram a declarar em alto e bom som. Martínez Estrada não oferecia uma análise serena, mas sim "uma investigação apaixonada, mais eficaz na penetração, mais arrojada e com maior possibilidade de repercussão"; e, inclusive, os jovens admiravam esse fervor, embora não subscrevessem todas as afirmações de seu ensaio.

A crise da década de 1930 elucidava o sentido de Radiografia de la pam$p a$, que, por sua vez, como num círculo hermenêutico, iluminava, ao menos parcialmente, o fundamento histórico dessa crise. Mallea também participou desse esforço pela verdade e pelo destino da nação, embora sua obra fosse perdendo o poder de interpelação inicial. O parecer dos jovens, mais estritamente daqueles que se reuniram na redação de Contorno, estabelecia uma ligação entre a interpretação dos anos de 1930 - a década infame, caracterizada pela fraude eleitoral e pelas perseguições políticas e grandes negociatas contra o interesse nacional - e uma interpretação da vida intelectual e literária desse período, que consistia em evocar os poucos que se levantaram contra o conformismo, rodeados pelo silêncio e desconcerto, quando não pela cumplicidade dos demais. No início da década de 1950, essa representação integrava a polêmica contra aqueles que se opunham à ordem política peronista, mesmo ocupando o centro do prestígio intelectual e controlando os dois órgãos da autoridade cultural: o suplemento dominical de La Nación e a revista Sur. Eles, os “maiorais", não foram os mestres que deveriam ser: "Não há exemplos: os inteligentes esquivaram-se, fracassaram, entregaram-se ou fugiram; e os de boa fé e coragem careceram de inteligência” (Viñas, 1953).

Os jovens "parricidas" interpretavam a vida ideológica da década de 1930 à luz das indagações e ansiedades do presente, e vice-versa. A interpretação falava do passado, mas também (e até mesmo mais) da posição de seus revisionistas, vinte anos depois; e, inclusive, o peronismo, visto principalmente em sua dimensão ético-política, podia ser compreendido por meio da ampla crise ainda não solucionada. Não obstante tratar-se de uma interpretação muito datada historicamente, essa retícula simplificadora da vida 
intelectual da década de 1930 deixou um amplo rastro. Mas, com o passar do tempo, e graças às pesquisas hoje disponíveis, a lente da "geração de 1945 ” já não parece utilizável para considerar o ensaísmo dos anos de 1930, nem para discernir a contribuição de seus textos fundamentais ao que já fora dito.

Ambiente político e cultural

Conforme o demonstra León Sigal, em uma sagaz análise de Radiografía de la pampa (cf. Sigal, 1991), a referência ao ambiente político da época é necessária, mas não suficiente para a compreensão do conjunto do pensamento argentino aqui considerado. Para situar esse ensaísmo em sua época, também é preciso considerar o ambiente cultural específico desses anos; ou seja, a mescla relativamente passageira de temas, inquietudes, formas e estímulos intelectuais que não procediam do contexto imediato da vida política, mas compunham o contexto ideológico da intelligentsia. Examinemos, sucintamente, alguns aspectos desse ambiente - ou de certo microambiente, como seria mais apropriado dizer -, visto que os pontos de referência não foram os mesmos para todos os setores do ambiente intelectual.

Entre os ensaios de pretensão científica que buscaram, tanto na Argentina, como em toda a América espanhola, definir o caráter ou a psicologia coletiva desses povos - para citar obras argentinas: Nuestra América. Ensayo de psicología social (1903), de Carlos O. Bunge, ou La anarquía argentina y el caudillismo: estudio psicológico de los origenes argentinos (1907), de Lucas Ayarragaray -, e o conjunto de ensaios de tipo ontológico sobre o ser nacional, interpôs-se a decadência do espírito positivista. Certamente, não se tratou de um fenômeno interno, mas sim de um reflexo, na cultura local, de um processo que fermentava no pensamento europeu desde o final do século XIX. A crise geral da civilização liberal capitalista, produzida pela Primeira Guerra Mundial, não fez mais do que encerrar esse processo. Por sua vez, o fracasso do positivismo acarretou, generalizadamente, o descrédito do chamado ponto de vista naturalista na análise da história e da cultura.

No ambiente intelectual argentino, o clima antipositivista adveio da Guerra. A partir de meados dos anos de 1920, já era moeda corrente a afirmação de que o positivismo constituía um corpo sem vida - esse era um tópico recorrente nas páginas de Inicial (1923-1927), que se proclamava "Revista da nova geração". Também Alejandro Korn deu a ele um atestado de óbito em um moderado artigo de 1927, "Filosofía argentina", que trata- 
va do estado da cultura filosófica no país (cf. Korn, 1927). Escrito para a revista Nosotros, por ocasião do vigésimo aniversário da publicação, o artigo abordava a atribuição dada a José Ingenieros de "defender a última brecha" (a do "cientificismo") de um ciclo filosófico tido como irreversivelmente terminado. Ingenieros faleceu em 1925, e La Revista de filosofía, que ele criara dez anos antes, exatamente como bastião contra as novas tendências, deixou de ser publicada em 1929.

$\mathrm{Na}$ época, os pensadores de referência eram Henri Bergson, Benedeto Croce, Oswald Spengler e José Ortega y Gasset. Eles simbolizavam a "nova sensibilidade" - segundo o termo cunhado por Ortega e adotado pelos jovens - e, embora não pertencessem a uma escola, tinham em comum a recusa ao mecanicismo, ao naturalismo filosófico e à razão abstrata. Durante algum tempo e em determinados círculos, Hermann Keyserling, uma dessas estrelas fugazes que cruzaram o firmamento intelectual da Europa entre as Guerras, também participou desse espaço de reconhecimento. De ascendência lituana, Keyserling estudara filosofia na Alemanha, e costumava viajar e escrever livros sobre os países visitados, figurando como principal protagonista. $\mathrm{O}$ que se admirava nele não era o seu talento filosófico, mas sim seus dotes como observador pungente da índole dos povos e de sua cultura. Depois de um giro pela América Latina, incluindo a Argentina, ele publicou Meditaciones suramericanas. Traduzido em 1933, o conjunto de visões da realidade hispano-americana que compunha o livro ganhou admiradores em todo o subcontinente. Na primeira de suas meditações, Keyserling diz que a América é o continente do terceiro dia da criação; isto é, uma parte do mundo ainda em fase primordial da formação cósmica, cujo habitante “é total e absolutamente um homem telúrico". Submetido, contudo, às forças da terra, o hispano-americano representava "o polo oposto ao homem condicionado e traspassado pelo espírito" - ou seja, o homem europeu (cf. Conde de Keyserling, 1933, pp. 15-39). Uma revisão de suas Meditaciones, de tom mais complacente do que o livro em relação à suscetibilidade argentina, foi publicada em 1931, no segundo número da revista Sur.

\section{O fator Ortega}

Porém, dos pensadores mencionados, nenhum desempenhou um papel equiparável ao de Ortega y Gasset. $\mathrm{O}$ estudioso israelense da história intelectual hispano-americana, Tzvi Medin, afirma que seria impossível escrever sobre a cultura desses países, no século XX, sem fazer referência à in- 
fluência desse filósofo espanhol, e defende essa tese em uma ampla e detalhada pesquisa (cf. Medin, 1994, p. 7). Provavelmente, em nenhum lugar a gravitação de Ortega foi maior do que na Argentina. Já sua primeira visita ao país, em 1916, quando ele permaneceu vários meses, representou um sucesso intelectual. No artigo citado anteriormente, Alejandro Korn enfatizava a dívida que a cultura filosófica argentina havia contraído com o filósofo espanhol: "A presença de Ortega y Gasset, no ano de 1917, foi um acontecimento para nossa cultura filosófica. Autodidatas e diletantes, tivemos a oportunidade de escutar as palavras de um mestre; alguns despertaram de sua letargia dogmática, enquanto muitos se deram conta, pela primeira vez, da existência de uma filosofia menos vulgar" (Korn, 1927, p. 57). A introdução do que poderíamos chamar de "fator Ortega" agiu como um catalisador: acelerou o processo de dissolução do positivismo e despertou nos aficionados dos estudos filosóficos a consciência de que para filosofar em consonância com sua época eles deveriam cultivar a filosofia como uma disciplina, um saber com características próprias. Além disso, em um meio comumente voltado quase exclusivamente para as tendências do pensamento francês, e, em menor escala, para as do mundo anglo-saxão, o espanhol proclamou que a grande filosofia estava sendo escrita em língua alemã. Doze anos depois, por ocasião de sua segunda viagem, o decano de Filosofia e Letras, Coriolano Alberini, atestará a ele esse reconhecimento: "Nós argentinos devemos a ele - não obstante qualquer discordância natural no embate filosófico - a revelação do que há de mais vivo na filosofia alemã contemporânea" (Alberini, 1928).

Mas, na cultura intelectual argentina, o "fator Ortega" não se circunscreveu ao âmbito acadêmico, nem à repercussão de seus seminários especializados, como aquele que realizou sobre Kant, em 1916. Desde a primeira visita, suas aulas públicas e conferências atraíram uma audiência muito maior do que a dos aficionados em questôes filosóficas, e ele levou essa atividade para além de Buenos Aires, alcançando Rosário, Tucumán, Córdoba e Mendoza. O interesse despertado pelo filósofo espanhol entre o público erudito da Argentina, sobretudo os jovens, criou as condiçōes de recepção a seus novos livros - particularmente, El tema de nuestro tiempo (1923) e La rebelión de las masas (1930) -, bem como à Revista de Occidente, que ele fundou em 1923, e também às obras que ele divulgou por meio da Biblioteca de Ideas del Siglo XX, e, posteriormente, da Biblioteca de Revista de Occidente. A metade dos exemplares da Revista de Occidente era distribuída na América espanhola, sendo a Argentina o seu principal destino. Suas páginas reuniam tudo o que, 
segundo Ortega, refletia o rumo da cultura ocidental nos mais variados campos do saber: a filosofia, a literatura, a psicologia, a estética, e também a sociologia, que deixaria de ser considerada como uma manifestação do espírito positivista para adquirir novo brilho ao ser cultivada por aqueles que possuíam cultura filosófica - o próprio Ortega dará o exemplo dessa outra maneira de conceber a sociologia, com La rebelión de las masas.

Por meio da revista e dos livros da publicação anexa, os representantes do "novíssimo pensamento" - segundo a expressão de Francisco Romero - despontaram no horizonte dos leitores argentinos (cf. Romero, 1952, p. 45). Entre esses autores, há dois que Martínez Estrada menciona como seus mestres ao idealizar Radiografia de la pampa: Oswald Spengler e Georg Simmel (com o primeiro, diz ele, "aprendi que a história é a biografia cultural dos povos, e não a crônica militar e diplomática", e com Simmel, "seu método configuracionista") (cf. Estrada, 1969, pp. 132-133). Ao chegar a Buenos Aires, em sua segunda visita, Ortega y Gasset deu um depoimento aos jornalistas argentinos, em que destacava com satisfação o que havia conseguido em doze anos de magistério intelectual: "Os jovens leram meus erráticos escritos e escutaram minhas indicaçôes sobre novos temas, ideias, mestres” (1981a, p. 94). Entre esses temas, poderiam ser destacados o da dinâmica geracional como motor do processo histórico, ou então a questão das elites governantes e as massas, principalmente em relação à sociedade contemporânea, os quais não tardaram a ser incorporados à linguagem do ambiente intelectual argentino. Porém, dentro do variado repertório de reflexóes propostas por Ortega, parece especialmente pertinente aquela que se refere à preocupação com o ser argentino e, mais abrangentemente, com o ser americano.

"Há algum tempo, a Argentina estende o pampa aos estrangeiros afamados, assim como estendemos a mão às quiromantes célebres", escrevia, em 1929, Victoria Ocampo (1999, p. 35). O artigo da futura diretora de Sur celebrava e agradecia a um desses adivinhos, José Ortega y Gasset, a agudeza dos ensaios voltados a decifrar o caráter dos argentinos. O americanismo de Ocampo se alimentaria da leitura de Ortega e de Waldo Frank, assim como dos diálogos com ambos. Foi o primeiro quem lhe recomendou ler Conde de Keyserling, e Ocampo não só seguiu o conselho como convidou o célebre viajante a visitar a Argentina. Além disso, o próprio Ortega recorrerá ao código telúrico na hora de interpretar as idiossincrasias do argentino, em seu famoso ensaio "La pampa... promesas", no qual ele não se contentava em descrever as paisagens, "porque as paisagens são organismos. Nelas, não só há coisas, como essas coisas são seus órgãos e exercem 
funções intransferíveis" (Ortega y Gasset, 1981c, p. 105). No pampa, ele encontrará uma metáfora da alma argentina.

Ortega não limitou o código da natureza (o espaço, o meio físico) à definição da psicologia coletiva dos argentinos, mas estendeu esse princípio à interpretação da totalidade do Novo Mundo. Em 1928, ele se referirá à questão, valendo-se de Hegel e indagando qual lugar este atribuiria à América no âmbito da história universal. Essa era a pergunta intencional que Ortega y Gasset se colocava em relação à Filosofia da história universal, cuja tradução para o espanhol acabava de ser publicada. Ele observará que a América não ocupa nenhum lugar no contexto histórico oferecido por essa obra, já que para Hegel ela é ainda apenas um porvir. "Quando o espaço excede”, explicava Ortega, "a natureza se apropria do homem. O espaço é uma categoria geográfica, não histórica”. Será que se o filósofo alemão revivesse, ele retificaria seu critério? Ortega não o crê, já que sob a "ultramodernidade" ele veria um tipo de espiritualidade primitiva, um despertar de algo novo: "Em suma, o que apreciaria da América seria precisamente uma nova e saudável barbárie" (Ortega y Gasset, 1981b, p. 91).

$\mathrm{Na}$ década de 1930, todas essas sugestōes pairavam no ar. Não quero dizer com isso que, na época, todos fossem orteguianos, na Argentina. Desde o início, eu havia encontrado ressalvas, notas irônicas e críticas, tanto na Revista de Filosofía - obviamente, enquanto ela sobreviveu - como depois, na obra de Aníbal Ponce, o seguidor marxista de José Ingenieros, e também nas de Alberto Palcos, Ramón Doll e Roberto Giusti. No entanto, não era dos críticos que procedia a agenda intelectual da "nova geração", uma autodenominação que já remetia à linguagem ideológica de Ortega; sendo que este, por sua vez, não fez mais do que estender os domínios por onde circulava sua palavra: desde 1923, ele publicava regularmente no jornal $\mathrm{La}$ Nación e, a partir de 1931, também passou a contar com outra tribuna amiga, a revista Sur. Os nomes dessas publicações poderiam dar margem a pensar que a autoridade de Ortega permaneceu no setor relativamente liberal do campo intelectual argentino; contudo, seu império também abarcou a família nacionalista, principalmente os jovens de origem católica, que queriam pensar conforme sua geração.

\section{O pensamento sobre a crise}

Também pairava no ar o tema da crise, um labirinto de desordens no mundo, diariamente transmitido pela imprensa: crise da economia, crise do 
regime liberal-democrático, desacerto sobre o rumo da cultura ocidental. Algumas análises sobre o declínio da Europa, nos anos pós-Primeira Guerra $-A$ crise do espírito, de Paul Valéry, e $A$ decadência do Ocidente, de Oswald Spengler -, realimentavam-se com os distúrbios da crise econômica. O experimento soviético na Rússia e a fórmula fascista na Itália, as duas negaçōes da civilização burguesa, representavam ameaça para alguns e esperança para outros, sem contar os descontentes, que recusavam as duas soluçôes.

A Argentina não fugia a essa ampla desordem dos pontos de referência que levava a pensar que os fatos precediam as ideias. A interpretação das alternativas da vida nacional começará a refletir a comoção geral. $\mathrm{O}$ liberalismo econômico, por exemplo, deixará de fazer parte do senso comum, entre as elites políticas e intelectuais, quer por ser considerado historicamente esgotado, quer por se entender que as circunstâncias aconselhavam limitá-lo, admitindo a intervenção estatal enquanto durasse o transe experimentado pelo mundo. Esse critério pragmático foi adotado pelo governo conservador do general Justo, com a gestão econômica dos ministros Federico Pinedo e Luis Duhau.

A interpretação das causas e a profundidade da crise variavam conforme as comunidades ideológicas, do segmento das esquerdas aos diferentes círculos da constelação nacionalista. Uma área do inconformismo intelectual dos anos de 1930, que não se inseria na órbita dessas correntes ideológicas, pode ser apreendida no Manifiesto del Frente de Afirmación del Nuevo Orden Espiritual (Fanoe), de 1932. Para seus signatários, a crise tinha dimensóes econômicas e políticas, embora sua base fosse cultural.

O trágico destino de nosso tempo faz com que sejamos obrigados a viver em um momento de confusão, em que o mundo - diante de um avançado processo de dissolução social, e tomado concomitantemente por uma profunda crise espiritual segue em busca de novos caminhos. O momento reclama e exige, portanto, esforços excepcionais de nossa geração. [...].

Enquanto esse problema (o da reconstrução da sociedade) é hoje fortemente colocado no campo social e se mantém por valiosos esforços, há uma notória falta de visão do conteúdo espiritual implícito em toda transformação da sociedade. Assistimos, assim, ao paradoxal espetáculo de movimentos, partidos e homens de autêntico fervor revolucionário em questões econômicas e políticas, que, no entanto, professam um hermético conservadorismo nmo campo cultural, a ponto de buscarem perpetuar formas espirituais típicas da ideologia burguesa do século XIX: biologia darwiniana, sociologia naturalista, metafísica materialista, ética e pedago- 
gia utilitárias, literatura e arte realistas etc. Não obstante seu esquerdismo econômico-social, eles são radicalmente reacionários no espírito (Manifiesto, 1968, pp. 297-298).

A declaração foi redigida por Saúl Taborda, um pensador cordobês familiarizado com as novas correntes filosóficas - conforme se pode perceber na linguagem do fragmento mencionado -, e assinada por vários intelectuais ainda jovens, mas com certo nome no meio cultural, como Carlos Astrada, Juan Montovani, Francisco e José Luis Romero, Jordán Bruno Genta, Luis Aznar, Aníbal Sánchez Reulet, José Babini, Jorge Romero Brest, entre outros. Embora o agrupamento desses declarantes resultasse efêmero, já que em pouco tempo o debate ideológico polarizado ao ritmo da situação mundial os levaria por caminhos divergentes, o episódio revela não só a rede de relações de Taborda, como também uma área de sensibilidade do meio intelectual argentino, na qual a ideia da crise como crise do espírito burguês havia deixado raízes.

Não era alheio a esse fato o livro de Carlos Alberto Erro, Tiempo lacerado, um dos ensaios sobre o ser nacional, publicado em 1936. "O homem atual se move em uma realidade dramática”, dizia ele, na introdução da obra em cuja sequência descrevia o tormentoso panorama do mundo. Membro da revista Sur, Erro não brilhava por seus dotes literários, embora valha a pena registrar seu comentário sobre o presente nacional, que nos faz notar o humor ideológico ao qual se integrava esse ensaísmo:

$\mathrm{O}$ atual momento argentino e, pode-se dizer, o período histórico em que nossa geração precisará lutar, caracteriza-se [...] por dois aspectos fundamentais: pela primeira vez, desde que o país se organizou constitucionalmente, nossa sociedade vem conhecendo várias dificuldades graves - seria possível fazer a história de algumas derrotas e de muitos erros -, ao mesmo tempo em que começa a adquirir consciência de suas próprias falhas. [...] Caberia dizer que para a Argentina chegou a hora do desengano, e caso fosse esta a conjuntura, seria preciso saudá-la com alvoroço, pois desenganar-se significa superar seu erro e aproximar-se de uma nova verdade (Erro, 1936, p. 207).

Os dois autores, cujos ensaios mais importantes serão examinados subsequentemente, identificaram, cada um a seu modo, os males que atormentavam o país e as ficções coletivas que residiam no fundamento do desengano, bem como a verdade que é preciso enunciar. 


\section{As ficções de Trapalanda}

Quando publicou Radiografia de la pampa, em 1933, Martínez Estrada já possuía uma obra poética muito apreciada entre os escritores. Filho de um casal de imigrantes espanhóis, nasceu na província de Santa Fé, em 1895. Os percalços familiares levaram-no de um lugar a outro, e seus estudos primários acompanharam esses deslocamentos, até serem concluídos em um colégio de Buenos Aires. Desde então, sua formação foi a de um autodidata - assim como muitos outros escritores argentinos da primeira metade do século XX -, e um autodidata voraz, "que atacava as letras e as ciências com a pressa de um viajante ambicioso" (Arrieta, 1966, p. 180). Durante anos, seu principal meio de vida foi um emprego no Correio Central, onde ingressou muito jovem, permanecendo até 1946 nessa ocupação burocrática que o mortificava ("tarefas inferiores, colegas vulgares e incompreensivos, horas melancólicas que lhe devoravam o dia”, escreve Rafael Arrieta, ao recordar as confidências do amigo).

A cena original, aquela em que se produz a revelação que o levará a escrever Radiografía de la pampa e a abandonar o culto à poesia - como o evocará Martínez Estrada, mais de duas décadas depois -, aconteceu nas ruas do centro de Buenos Aires, logo após o golpe de Estado de 6 de setembro de 1930:

Ainda me lembrava muito bem das festas do Centenário, e, repentinamente, tive a impressão de que retrocedia vinte anos atrás, como se nem eu, nem os que nos rodeavam tivéssemos mudado. $\mathrm{O}$ tempo era um sonho. Esse choque ou trauma revelou-me uma chave de interpretação válida para a releitura do Facundo e também para o texto em relevo, e para o tato do sistema Braille, que eu estava presenciando.

Dirigindo-se ao amigo Samuel Glusberg, que o acompanhava, ele disse: "Ouça: U-ri-buuru; é o mesmo que I-ri-gooo-yen". Glusberg o incentivou a escrever sobre isso, nascendo assim Radiografía de la pampa. O episódio não interessa aqui pelo que eventualmente possa nos ensinar sobre a motivação da obra, mas sim por nos mostrar, muito sinteticamente, a tese que a preside: sob os acontecimentos externos, como os fatos políticos, e a época em que estes transcorreram, uma realidade mais profunda e permanente rege as vicissitudes da Argentina. Esse duplo plano da vida nacional - um plano das formas, ostensivo embora superficial; e um outro, real ou de maior eficácia, 
múltiplo em suas manifestações - encontra-se na origem, ou seja, no próprio começo daquilo que se converterá no país dos argentinos.

O livro não se desenvolve segundo a linha de uma demonstração, nem na forma de um relato. Mais do que um ensaio, seria preciso falar em uma cadeia de ensaios reunindo, a cada vez, como variaçôes, um conjunto de motivos ou de temas básicos. Esse esquema formal não é estranho à ideia que norteia Radiografia de la pampa - de que a repetição, e não a mudança, constitui o fundo secreto do processo argentino. As diferentes partes do livro são como canais; ou seja, cruzam todas as épocas da formação nacional, desde a conquista até o presente, porém sem transições. Não há muitos sobrenomes, embora alguns poucos sejam repetidos por seu valor simbólico: Rosas, Irigoyen, Sarmiento, Alberdi, Pellegrini. Uma linguagem de grande tensão literária, mais rica em termos figurativos do que argumentativos, povoada de associações, analogias e visões sintéticas, às vezes sugestivas, noutras simplesmente arbitrárias, estabelece os tópicos de uma obra intelectualmente ambiciosa.

No primeiro ensaio de Trapalanda, Martínez Estrada apresenta o surgimento do (auto)engano, que, em sua opiniāo, se encontrava na raiz da frustração nacional. $\mathrm{O}$ sonho e a ilusão desmedida já dominavam a mente daqueles que no século XVI abandonaram a Europa para aventurar-se na conquista do novo mundo descoberto por acaso. Eles "chegavam prevenidos contra a bem simples e pobre realidade da América. Já figuravam-na povoada de monstros, dificuldades e riquezas" (Estrada, 1991, p. 10). Trapalanda, a quimérica cidade dos Césares indígenas, era essa terra esplêndida; mas a América não se tornou a América fabulosa, cheia de tesouros. No entanto, a resposta do conquistador não foi admitir o desengano: sua intenção não fora a de vir povoar, trabalhar e esperar. Sobre a natureza primordial que constituía a realidade americana, sobrepor-se-á a realidade do sonho. "Sobre uma terra imensa, que era a realidade impossível de modificar, erguer-se-iam as obras precárias dos homens. De uma expedição a outra, descobriam-se escombros e, novamente, a realidade da terra ocultando a realidade da utopia" (Idem). A vontade quimérica persistirá, trará seus códigos, suas instituições, suas cidades, e o ocupante acabará por ficar. Lá onde, como no futuro território argentino, não encontrar nada, senão terras desoladas, fará da acumulação destas o seu tesouro.

Esta terra, que não tinha metais à flor do solo, nem antigas civilizações para destruir, e que não possuía cidades fabulosas, mas bandos de selvagens nus, continua 
sendo um bem metafísico na cabeça do filho do Conquistador. Ela constituiu um bem de poder, domínio, hierarquia. Possuir terra era possuir cidades que seriam edificadas no futuro, dominando pessoas que as povoariam depois (Idem, p. 14).

Certamente, não se tratava de ouro em barra, mas de uma riqueza virtual, que, contudo, alimentou, desde o início, os delírios de grandeza. Seguiu-se vivendo "com aquelas minas de Trapalanda na alma" (Idem, p. 14). A realidade elementar do "informe" irromperá sempre para contradizer ou domesticar, com sua verdade de terra que ainda não fora moldada pela história (o espírito), ou que a ilusão edificara. Suas forças primitivas, que tudo penetravam, vingavam-se e obrigavam a reconhecer seu império. Mesmo as cidades, que o medo e o desejo de domínio erigiram contra esse contorno natural, eram penetradas pelo vento vindo da planície. Também Buenos Aires, a metrópole de alma europeia que realiza a ficção de Trapalanda, mostra a presença múltipla, embora disfarçada, da barbárie. Nesse sentido, Rosas estava mais próximo da verdade do que Sarmiento, o símbolo do projeto e da ação civilizadores. A modernização do país, após a queda de Rosas, coincidiu com a imposição de códigos e instituiçóes que atuaram como um sistema coercitivo, pois não correspondiam aos costumes da terra. Em outras palavras, reproduziu-se a violência do conquistador. Para Sarmiento, civilização e barbárie eram os termos de uma antinomia, e esta era a cegueira contida em sua grande obra:

Não viu que a cidade era como o campo, e que nos corpos novos reencarnavam as almas dos mortos. Vencida esta barbárie, todos os vícios e as falhas de estruturação e conteúdo adquiriram o aspecto da prosperidade, dos avanços mecânicos e culturais. Os baluartes da civilização foram invadidos por espectros que se consideravam aniquilados [...]. Conforme essa obra e essa vida imensas vão caindo no esquecimento, a realidade profunda nos é devolvida. Temos de aceitá-la valorosamente, para que ela deixe de nos perturbar: trazê-la à consciência, para que se desvaneça e possamos viver unidos com saúde (Idem, pp. 341-342).

Esse é o parágrafo final de Radiografía de la pampa. Não é difícil reconhecer a dívida de seu preceito hermenêutico para com o freudismo - negação da realidade que é fonte de desprazer, satisfação imaginária do desejo, reavivamento do reprimido, compulsão à repetição -, e Martínez Estrada considerava que sua obra oferecia uma espécie de psicoanálise da alma argentina. Inclusive, sua exortação final a aceitar a realidade profunda ("trazê- 
la à consciência") tem raiz freudiana. A visão do Novo Mundo insere-se nesse esquema como reino do espaço e da extensão, em oposição ao reino do tempo histórico e do espírito, que é a Europa, em uma visão que procedia de Ortega e de Keyserling.

É com esses códigos que Martínez Estrada interpreta episódios históricos, personalidades da vida pública, tipos sociais, a vida rural e urbana, processos econômicos e políticos, a universidade e o tango; enfim, o conjunto da experiência argentina analisada como um grande texto cifrado. $\mathrm{E}$ o que revela o deciframento? Imposturas, disfarces, inautenticidade, sobre o fundo do contraste constante entre sonho e realidade. A tarefa de deciframento não requer apenas destrezas hermenêuticas, mas também coragem intelectual de quem se julga disposto a dizer a verdade, pois ela obriga a enfrentar o proibido. A noção de tabu é reiterada no texto. Por exemplo: "Ninguém disse a verdade sobre Alvear, Pueyrredón, Rondeau, Güemes, Mitre, Urquiza, Lavalle, Dorrego, Rosas. Suas figuras verdadeiras são tabu" (Idem, p. 326).

Só seria possível escapar do ciclo invariável de frustrações tendo-se o mérito de aceitar a realidade reiteradamente negada. Em nenhuma parte de Radiografia... o significado disso se esclarece em termos efetivos, dando apenas a entender que as elites modernizadoras (ou civilizadoras) caminhavam muito rápido, e que essa pressa em alcançar o futuro não permitia que o pensamento se conjugasse com a realidade. Um mundo simples e uma inteligência complicada e sonhadora, "capaz de exercícios mais enérgicos do que as coisas o exigem" (Idem, p. 331). Sarmiento foi o "primeiro dos que ergueram pontes sobre a realidade", e a "geração de 1880 representa a forma coletiva típica dessa pseudoestrutura de civilização" (Idem, p. 337). Esse movimento de futuração incessante impediu o aprofundamento, levando à improvisação constante. À ciência do improvisador, Martínez Estrada contrapôs a ciência do timoneiro, cujo depositário era o caudilho, mais cauteloso e mais próximo da realidade americana.

Radiografia de la pampa prestava-se (e se presta) a mais de uma leitura, e cada uma delas pode encontrar no texto o parecer que julgar esclarecedor, ou a ideia para ser citada. Existiu, assim, um Martínez Estrada para José Luis Romero (Argentina: imágenes y perspectivas), para Héctor A. Murena (El pecado original de América), para Rodolfo Kusch (La seducción de la barbarie), e também para os jovens de Contorno, conforme já vimos. Também na opiniāo do nacionalista Máximo Etchecopar, Radiografía de la pampa 
representava um livro ímpar na literatura do país: "Constitui o único enfrentamento veraz à realidade sociológica do país, nas circunstâncias em que tal realidade se presta a descobri-la em toda a sua dramática e rude significação" (Etchecopar, 1956, p. 70).

\section{Os dois países}

A análise e a mensagem de Eduardo Mallea, em Historia de una pasión argentina, eram mais unívocas. Mallea nasceu em 1903, na cidade de Bahía Blanca, onde passou sua infância e parte de sua adolescência. Em 1916, mudou-se com a família para Buenos Aires, onde concluiu o bacharelado e iniciou seus estudos na Faculdade de Direito. Provinha de uma família de classe média de antiga estirpe, embora sem fortuna. Seu pai, um médico entusiasta das letras, foi quem lhe incutiu a devoção pelo mundo dos livros. Em Buenos Aires, não tardou a descobrir sua vocação literária, dando suas primeiras demonstraçôes como escritor. Em 1926, publicou Cuentos para una inglesa desesperada e abandonou seus estudos de advocacia, ingressando, no ano seguinte, no jornal La Nación (1927). Quase uma década separa a publicação de seu primeiro livro e o ciclo literário a que dará início com o ensaio Conocimiento y expresión de la Argentina e a novela Nocturno europeo, ambos publicados em 1935. Historia de una pasión argentina, de 1937, pertence ao referido ciclo, sendo que, à época, Mallea era diretor do suplemento literário de La Nación e membro do conselho editorial de Sur, cuja criação impulsionou (cf. Pasternac, 2002).

Historia de una pasión argentina constitui uma autobiografia espiritual que entrelaça relato e reflexão: o relato de uma consciência que busca a si mesma, por meio de acasos e crises, e a reflexão sobre o sentido desse questionamento dirigido ao ser da nação, a nação essencial, aquela a que aspiram os argentinos "insones", como Mallea denomina seus semelhantes; ou seja, aqueles que, como ele, estavam desgostosos com o país exterior, "visível”. O mal-estar começa em Buenos Aires, a grande metrópole, que é o local por excelência da Argentina oficial, a Argentina burguesa. No ensaio de Mallea, o termo burguês não indica uma classe socioeconômica, mas uma categoria de ordem ética e cultural: agrupa os "exclusivamente subordinados ao coeficiente de sua prosperidade pessoal", sem fervor e sem outro desejo que o da existência aparente. "Não vida, aparência, saúde, gozo, progresso, mas sim aparência de saúde, aparência de gozo, aparência de progresso" (Mallea, 1961, p. 74).Uma barbárie íntima localizava-se no fun- 
do dessa burguesia de refinamento falso e exterior. Os habitantes da Argentina visível, satisfeita, beócia, sem vida autêntica, não estavam apenas no mundo dos negócios. Esses homens

[...] enchiam os claustros das faculdades, os laboratórios científicos, as instituiçōes de apoio à arte; os professores paraninfos, em não poucas escolas, não poucas academias [...] esparramavam-se e corriam como uma onda espessa, inundando as tribunas do parlamento, os clubes exclusivos, os escritórios da administração nacional [...] (Idem, p. 75).

O hinterland constituía o outro território da existência nacional. "Se há dois homens no mundo, que são psicológica, ética e socialmente diferentes, esses dois homens são o habitante do hinterland e o habitante da cidade. $\mathrm{Na}$ dimensão dessa diferença, pareceu-me sempre residir a dimensão de nosso possível crescimento até a integração positiva de nosso destino" (Idem, p. 84). Moralmente desgostoso com o país visível, embora fictício, Mallea percorre esse outro território, o do país profundo, para ir ao encontro do tipo humano no qual verá o fundamento de uma alternativa para a desordem espiritual e a vida egoísta e sem aspirações da Argentina burguesa. Quais são os atributos do habitante do hinterland argentino? Sobriedade, orgulho sem alarde, ausência de falação, sabedoria simples, integridade diante das adversidades, naturalidade. "Desejo aludir ao gaúcho, e também ao camponês, ao agricultor, ao fazendeiro?” Aqui, tampouco se tratava de uma posição na estrutura social, mas sim de um estado do espírito, o do "homem argentino eticamente bem definido, que se parece - até mesmo identificando-se de modo assombroso com eles - com o próprio clima, a forma e a natureza da terra argentina" (Idem, p. 89). Mallea encontrava a fonte da nacionalidade na fisionomia moral desse homem. Mas o fato de que esse tipo humano tenha seu meio mais adequado no hinterland não significa que ele também não possa ser encontrado nas cidades. "O importante não é onde esses homens estão, mas como eles são" (Idem, p. 89).

A ideia e a imagem do argentino de qualidade, apresentadas por Mallea, já estavam esboçadas em Lugones, Borges, Güirades. Em outras palavras, Historia de una pasión argentina organizava e estabelecia um tópico. A opinião poderia ser estendida a outros temas que o autor reunia ao longo do ensaio. Por exemplo, a condenação de uma forma de vida que só parece poder se pautar pelo desejo de riqueza, o comentário antipositivista, a censura à vida pública e acadêmica, a necessidade de uma nova ordem espiri- 
tual. Para Mallea, a Argentina estancou espiritualmente, depois de Caseros: "Desde a época da organização nacional, o trabalho da Argentina visível tem sido principalmente um trabalho sem fantasia, um trabalho desprovido de espiritualidade" (Idem, p. 97) - e isso implicava um julgamento sobre o trabalho da geração de 1880 . O nacionalismo, ainda que não na versão violenta e extrema demonstrada na Europa das ditaduras, devia ser um fator do renascimento espiritual do país.

$\mathrm{Na}$ viagem dentro de si mesmo, que é, simultaneamente, a viagem ao ser verdadeiro da nação, ocorre o encontro com Waldo Frank, o escritor do norte em quem Mallea descobre um novo sentido do americanismo. "Com que emoção e com que gratidão recordo aqueles dias, aquelas manhãs frescas na casa transplantada! Um, ilustre, mais velho; o outro, obscuro, mais jovem: éramos dois homens atentos à causa americana; um, grande; o outro, pequeno; mas ambos movidos por uma devoção semelhante" (Idem, p. 120). Em nenhum outro texto anterior a Historia de una pasión argentina, o americanismo de Sur obteve exposição mais calorosa. Tal americanismo distanciava-se de qualquer ufanismo e assumia-se como dever de uma elite que não se pretendia apenas como uma minoria culta, mas também como elite responsável. Esse dever implicava o quê? Viver em um território ainda inóspito para o espírito e sob o signo da improvisação cultural; fazer disso uma escolha, e empenhar-se na realização da aspiração contida na América. "O que importa é a imagem americana que carregamos como uma promessa a cumprir, e como um acordo a realizar" (Idem, p. 140). Um americanismo da vontade - poder-se-ia dizer -; estoico como o nacionalismo também propugnado por Mallea, para realizar a promessa descumprida da Argentina. Americanismo e nacionalismo remetem, ambos, ao labor de uma minoria que se via desterrada. "Desterrados somos todos nós, argentinos. Desterrados do espírito, da civilização da qual viemos, daquele vínculo ancestral no qual, diferentemente de nós, os homens produziram arte, pensamento, filosofia." Aceitar o desterro, não se apressar em sair da "pátria interior", persistir em uma "aridez que busca tornar-se fértil" (Idem, p. 202).

O ensaio de Mallea não era menos elaborado literariamente do que $R a$ diografía de la pampa. Entretanto, o modo de sua formulação era outro, mais inclinado ao pateticismo e à veemência: a dramatização do mal-estar alterna com o lirismo das descobertas. A esperança ofertada - como o observou Mariano Picón Salas - era a de um destino mais moral do que material; destino que se alcançava por um caminho talhado de expiações, renúncias e abstençôes (cf. Salas, 1977, p. 83). Durante mais de uma década, ele 
foi devotamente lido pela comunidade de "insones" aos quais interpelava, não só na Argentina, como também em toda a América espanhola.

\section{Referências Bibliográficas}

Alberini, Coriolano Alberini. (1928), "Ortega y Gasset en la Facultad de Filosofía y Letras". Sintesis, ano II, n. 19.

ARriETA, Rafael Alberto. (1966), Lejano ayer. Buenos Aires, Ediciones Culturales Argentinas.

Borello, Rodolfo. (1993), "Radiografía de la pampa y las generaciones de 1925 y de 1950. Interpretaciones y discípulos”. In: Estrada, Martínez, Radiografia de la pampa. Buenos Aires, Colección Archivos/FCE.

Buchbinder, Pablo. (2005), Historia de las universidades argentinas. Buenos Aires, Sudamericana.

“CARTA a Ortega y Gasset” [19/7/1930]. (1980), Sur, n. 347, jul./dez.

Conde de Keyserling. (1933), Meditaciones suramericanas. Madri, Espasa-Calpe.

Erro, Carlos Alberto. (1936), Tiempo lacerado. Buenos Aires, Sur.

Estrada, Ezequiel Martínez. (1969), "Sobre Radiografia de la pampa (preguntas y respuestas)". In: . Leer y escribir. México, Joaquín Mortiz, pp. 132-133. . (1991), Radiografia de la pampa. Buenos Aires, Losada.

Etchecopar, Máximo. (1956), Esquema de la Argentina. Buenos Aires, Emecé.

Gramuglio, María Teresa. (2001), "Posiciones, transformaciones y debates en la literatura”. In: CatTARUZZA, Alejandro (org.), Crisis económica, avance del Estado e incertidumbre politica. Nueva historia argentina, tomo VII. Buenos Aires, Sudamericana.

Korn, Alejandro. (1927), "Filosofía argentina”. Nosotros, n. 219-210, ano XXI, t. LVII. Mallea, Eduardo. (1961), Historia de una pasión argentina. Buenos Aires, Sudamericana.

"Manifiesto del Frente de Afirmación del Nuevo Orden Espiritual (Fanoe)". (1968), In: Ciria, Alberto \& Sanguinetti, Horacio, Los reformistas. Buenos Aires, Jorge Álvarez, pp. 297-298.

Medin, Tzvi. (1994), Ortega y Gasset en la cultura hispanoamericana. México, FCE. Monegal, Emir Rodríguez. (1956), El juicio de los parricidas. Buenos Aires, Deucalión. OCAMPO, Victoria. (1999), "Quiromancia de la pampa”. In: Testimonios. Séries primeira a quinta. Seleção, prólogo e notas de Eduardo Paz Leston. Buenos Aires, Sudamericana.

Ortega y Gasset, José. (1981a), "Aviso a los periodistas argentinos". In: Meditación del pueblo joven y otros ensayos sobre América. Madri, Revista de Occidente/Alianza Editorial. 
(1981b), "Hegel y América". In: Meditación del pueblo joven y otros ensayos sobre América. Madri, Revista de Occidente/Alianza Editorial. (1981c), "La pampa... promesas". In: Meditación del pueblo joven y otros ensayos sobre América. Madri, Revista de Occidente/Alianza Editorial.

PASTERNAC, Nora. (2002), Sur: una revista en la tormenta. Los años de formación 19311944. México, Paradiso.

Romero, Francisco. (1952), "Indicaciones sobre el pensamiento filosófico en la Argentina”. In: . Sobre la filosofía en América. Buenos Aires, Raigal.

Romero, José Luis. (1996), Breve historia de la Argentina. Buenos Aires, FCE.

SAlas, Mariano Picón. (1977), Sarmiento, Lugones, Mallea. Buenos Aires, Publicaciones de la Embajada de Venezuela.

SigAL, León. (1991), "La radiografía de la pampa: un saber espectral”. In: EsTRADA, Martínez. Radiografia de la pampa. Buenos Aires, Losada.

VIÑAS, Ismael. (1953), "La traición de los hombres honestos". Contorno, n. 1, novembro. . (1954), Contorno, n. 4, dezembro.

. (2004), "Eduardo Mallea”. In: Avaro, Nora \& Capdevila, Analía. Denuncialistas. Literatura y polémica en los '50. Buenos Aires, Santiago Arcos.

\section{Resumo}

\section{Um mundo em crise}

Este estudo tem por objeto analisar um segmento do pensamento argentino da década de 1930, representado no ensaísmo sobre a "alma”, ou o caráter nacional. Esse ensaísmo produziu alguns textos que se transformaram, por meio da crítica, em clássicos da reflexão sobre o país - tais como Radiografia de la pampa, de Ezequiel Martínez Estrada, e Historia de una pasión argentina, de Eduardo Mallea -, e que se gestaram sobre a base de uma crise política - sua primeira exteriorização foi o golpe de Estado de 1930 - e de uma desordem mais ampla dos pontos intelectuais de referência, em consequência da falência do positivismo entre as elites culturais. O dissabor provocado pelo contexto político nacional se mesclou ao mal-estar oriundo do pensamento europeu sobre a crise - crise do espírito, da ordem liberal e do capitalismo -, e esse amálgama alimentou um estado de descontentamento intelectual que ganhou forma na reflexão ensaística. De modo cada vez mais amplo, esse gênero dá início a uma rigorosa revisão da Argentina liberal, no âmbito de cuja produção destacam-se os referidos ensaios de Martínez Estrada e de Mallea, que serão analisados na parte final do presente estudo.

Palavras-chave: Ser nacional; Americanismo; Intuicionismo; Intelectuais. 


\section{Abstract}

\section{A world in crisis}

This study analyzes a sector of Argentine thought from the 1930s, represented in the essays on the national 'soul' or character. This essay writing produced a number of texts that were transformed, through critical appraisal, into classics on the country itself such as Radiografía de la pampa by Ezequiel Martínez Estrada, and Historia de una pasión argentina by Eduardo Mallea - and which emerged out of a political crisis whose first notable effect was the 1930 coup d'état - and a more widespread disruption of the intellectual points of reference caused by the exhaustion of positivism as a paradigm among the cultural elites. The unease provoked by the national political context merged with the unease stemming from European thought concerning the crisis - the crisis of spirit, of the liberal order and of capitalism - and this amalgam fed a state of intellectual discontent that took concrete form in the essay. In an ever broader way, this genre stimulated a profound revision of liberal Argentina. Among the texts involved in this process we can highlight the essays by Martínez Estrada and Mallea, analyzed in the final part of the study.

Keywords: National being; Americanism; Intuitionism; Intellectuals. 